\title{
МУЛЬТИМЕДІЙНІ ТЕХНОЛОГІЇ У ПРОФЕСІЙНІЙ ПІДГОТОВЦІ ФАХІВЦІВ МУЗИЧНОГО МИСТЕЦТВА
}

\author{
Мей Фан \\ здобувач третього (освітньо-наукового) рівня вищої освіти кафедри \\ освітології та інноваційної педагогіки, Харківський національний \\ педагогічний університет імені Г. С. Сковороди, м. Харків, Україна
}

У статті проаналізовано зміст поняття «мультимедіа», зміст мультимедійних технологій у вищій освіті. Показано види мультимедійних курсів у підготовці фахівців музичного мистецтвв: відеолекція, лекція мультимедіа, аналогові навчальні видання. Доведено, щуо впровадження мультимедійних технологій у освітній процес сприяє підвищенню якості підготовки фахівців музичного мистецтвва.

Ключові слова: мультимедійні технологї, підготовка фахівців музичного мистецтва.

The article analyzes the content of the concept of «multimedia», the content of multimedia technologies in higher education. The types of multimedia courses in the training of specialists in musical art are shown: video lecture, multimedia lecture, analogue educational publications. It has been proven that the introduction of multimedia technologies in the educational process improves the quality of training specialists in musical art.

Key words: multimedia technologies, training of specialists in musical art.

Аналіз наукових публікацій доводить, що значний внесок у вивчення питань значення інформаційних технологій для навчання й освіти зробили такі українські вчені: М. Бубнова, М. Кохлер, П. Мішра, О. Пеньковець, О. Семеніхіна, О. Скафа, О. Спірін та ін. Формуванню професійної компетентності засобами мультимедійних технологій у мистецькій освіті присвячена монографія Л. Гаврілової.

Для того, щоб визначити шляхи застосування мультимедійних технологій у професійній діяльності майбутніх фахівців музичного мистецтва необхідно з'ясувати сутність та зміст цієї дефініції.

Термін мультимедіа — латинського походження, що поширився за рахунок англомовних джерел («multy» — множинний, складний та «media» середовище, засіб). У перекладі з латинської — «мультимедіа» означає «множинний засіб» або «багато середовищ». Оскільки технології мультимедіа $є$ комплексними, окремі їх елементи мають самостійні терміни, де 
слово «мультимедіа» трансформується в прикметник «мультимедійний/а»: мультимедійна система, мультимедійні програми [3, с. 45].

Щодо змісту цього поняття, то зазначимо, що у всесвітній доповіді ЮНЕСКО (1998 р.) цей термін визначають як «здатність подавати текстуальні зображення та звук користувачеві» [1, с. 12]. О. Шликова вважає, що мультимедіа — це «полісередовище», єдиний простір, який в синкретичному вигляді поєднує різні види та засоби надання інформації (текст, графіку, звук тощо) [5, с. 23]. О. Пушкарь наголошує, що мультимедіа є сучасною інформаційною технологією, яка об'єднує за допомогою комп'ютерних засобів графічне та відео зображення, звук та інші спеціальні ефекти [4, с. 34].

У науковій та технічній літературі зустрічаються різні тлумачення поняття «мультимедіа» (ММ) залежно від того, де воно використовується. У всесвітній доповіді ЮНЕСКО (1998 р.) «мультимедіа» розглядають як здатність подавати текстуальні зображення та звук користувачеві [1, с. 12]. Ю. Машбиць трактує ММ як багатоканальне середовище, що видає інформацію в різноманітних модальностях [2, с. 56]. Можна зробити висновок, що ММ є сучасною інформаційною технологією, що об’єднує за допомогою комп'ютерних засобів графічне та відео зображення, звук та інші спеціальні ефекти.

Мультимедійні технології в освіті використовують для створення навчальних курсів (E-learning), довідників, енциклопедій та збірників. За останні роки, у зв'язку із появою мультимедійних технологій, теорія навчання була значно розвинена, виділено окремі напрями досліджень, такі як теорія когнітивного навантаження та мультимедійне навчання.

Мультимедійні засоби навчання у системі вищої освіти сприяють удосконаленню діяльності викладача, підвищують ефективність освітнього процесу та якість підготовки майбутніх фахівців. Застосування сучасних мультимедійних технологій у процесі підготовки фахівців музичного мистецтва сприяє інтенсифікації навчального процесу, стимулює розвиток уяви та мислення студентів, дозволяє збільшувати обсяг навчального матеріалу, формувати дослідницькі та аналітичні вміння, приймати самостійні рішення в умовах проблемних ситуацій.

Вважаємо, що для організації вивчення теоретичного матеріалу можуть бути використані такі види мультимедійних курсів, як: 
- відеолекція, коли інформаційний матеріал викладач записує на відеоплівку. Відеолекція може бути доповнена мультимедійними додатками, що іiі ілюструють. Такі доповнення збагачують iï зміст, роблять виклад лекції більш привабливим для студентів. Перевагою цього засобу викладу матеріалу виступає можливість прослухати лекцію у будь-який час, повторно звертаючись до найбільш складних місць;

- лекція мультимедіа. У процес організації самостійної роботи над лекційним матеріалом можуть використовуватися інтерактивні комп’ютерні навчальні програми. Наприклад, навчальні посібники, в яких теоретичний матеріал завдяки використанню мультимедійних засобів структурований таким чином, що кожен студент обирає для себе оптимальну траєкторію вивчення матеріалу, зручний темп роботи, що відповідає психофізіологічним особливостям його сприйняття. Навчальний ефект у мультимедійних програмах досягається не лише за рахунок змістової частини і дружнього інтерфейсу, але і за рахунок використання, тестуючих програм, які дозволяють студенту оцінити рівень засвоєння теоретичного матеріалу;

- традиційні аналогові навчальні видання: електронні тексти лекцій, опорні конспекти, методична допомога для вивчення теоретичного матеріалу тощо.

Також, мультимедійні засоби у процесі підготовки майбутніх фахівців музичного мистецтва можуть бути представлені в якості електронних підручників, самостійно підготовлених викладачем матеріалів, презентацій інформації за допомогою програми Power Point, відеометодів, рольової гри, електронної інтерактивної дошки тощо.

Узагальнюючи вищевикладене, можемо зробити висновок, що впровадження мультимедійних технологій у процес професійної підготовки майбутніх фахівців музичного мистецтва дає змогу студентам:

1) розвивати свій досвід з опорою на притаманні їм психологічні особливості та індивідуальні здібності;

2) формувати вміння та навички інформаційної та комунікативної взаємодії;

3) оптимально використовувати свій навчальний час;

4) формувати дослідницькі уміння, приймати оптимальні рішення;

5) формувати вміння застосовувати мультимедійні технології у майбутній професійній діяльності; викладачам: 
Розділ II. Особистісні та соціальні детермінанти духовно-інтелектуального виховання і навчання в системі неперервної освіти

- збільшувати обсяг навчального матеріалу для творчого засвоєння і використання його студентами;

- оптимально використовувати навчальний час, розробляти та застосовувати оригінальні методи викладання;

- підвищувати свій рівень мультимедійної грамотності.

Отже, впровадження мультимедійних технологій сприяє підвищенню якості підготовки фахівців музичного мистецтва.

\section{Список використаних джерел:}

1. Всемирный доклад по образованию, 1998 г. : Учителя, педагогическая деятельность и новые технологии. Париж : ЮНЕСКО, 1998. 175 с.

2. Дистанційне навчання: психологічні засади : монографія / за ред. М. Л. Смульсон. Кіровоград : Імекс-ЛТД, 2012. 240 с.

3. Жалдак М. И. Основы информационной культуры учителя. Использование информационной технологии в учебном процессе. Київ : МНО УССР. КДПИ им. А. М. Горького, 1990. С. 3-24.

4. Пушкарь О. І. Інформатика: Комп'ютерна техніка. Комп'ютерні технології. Київ, 2002. 704 с.

5. Шлыкова О. Культура мультимедиа : учеб. пособ. Москва, 2004. 415 с. 